\title{
Corporate responsibility aspects of food banks network in the Czech Republic regarding the need of their economic sustainability
}

\author{
Lukas Polacek $^{1,}$, Jan Vavrina ${ }^{2, *}$ \\ ${ }^{1}$ Mendel University in Brno, Faculty of Business and Economics, Department of Business \\ Economics, Zemedelska 1, 61300 Brno, Czech Republic \\ ${ }^{2}$ Mendel University in Brno, Faculty of Business and Economics, Department of Business \\ Economics, Zemedelska 1, 61300 Brno, Czech Republic
}

\begin{abstract}
.
Research background: Food banks, in their current form, provide services free of charge, but their activities cannot be conducted without public subsidies. Specifically, these are operational and investment subsidies mainly from the resources of the Ministry of Agriculture of the Czech Republic. Thus, the tendency to change the current servicing scheme, mainly from the economic point of view, becomes a growing interest area for food banks and respective stakeholders.

Purpose of the article: Purpose of the article is to identify current best practice of food banks sector and to find common aspects of the financial position of food banks in the Czech Republic, using their financial statements and approaches of technical financial analysis in application on the sample of entities.

Methods: Authors use general methods of analysis and synthesis of relevant scientific articles and studies with respect to the fact that the problem area of effective and efficient activities in the CEE countries or even Europe is quite rare. There are employed data from accessible financial statements of currently existing 15 food banks in the Czech Republic.

Findings \& Value added: This article provides an initial outcome of an ongoing specific research project on sustainable service of food banks in the frame of corporate responsible activities within a globalized food manufacturing and food supply chain industry. Authors fill with partial results of this article a gap in the research of the sustainable food bank activities in the CEE countries.
\end{abstract}

Keywords: food banks; corporate responsibility; food supply chain; food waste

JEL Classification: $Q 18 ; D 22 ; C 55$

\footnotetext{
*Corresponding author: jan.vavrina@mendelu.cz
} 


\section{Introduction}

Food banks in their current form began to be established in the Czech Republic after 2006, in the context of a legislative platform that anchors their activities in the amendment of the Act on Food and Tobacco Products No. 110/1997 Coll. According to the aforementioned law and order legislation document, food banks are thus considered as nonprofit organizations, collecting and storing food free of charge for the purpose of allocating it to humanitarian or charitable organizations that provide food aid to clients of social services. According to the aforementioned Act on Food and Tobacco Products, free of charge food providers are food business operators in the Czech Republic, who place food on the market in an establishment with a sales area of more than $400 \mathrm{~m} 2$.It practically means a free provision of food that does not fully comply with the requirements set by the Food Act or directly applicable European Union legislation governing food requirements, but is safe for human consumption (e.g. incorrect labelling of products, products with damaged packaging, products after periods of minimum durability or otherwise qualitydeficient products at a level that does not reduce their food safety). Food banks can therefore be considered as independent actors in the public interest in reducing food waste as well as social responsibility in relation to poverty and related nutritional needs of the population groups concerned [1-3].

At present, there are 15 regional food banks operating in the Czech Republic, as well as a common central warehouse, which are associated within the Czech Federation of Food Banks. Although food is provided free of charge to these banks, their activities depend on public budget subsidies. Specifically, these are operating and investment subsidies mainly from the resources of the Ministry of Agriculture of the Czech Republic, in connection with the financial framework of the EU Common Agricultural Policy that is applicable in member countries [4]. Efforts are therefore intensifying to bring new efficiency aspects to their activities or tendencies to change the current economic scheme of activities not only of domestic food banks, respectively $[4,5]$. It can be also pointed out at socio-economic aspects of food surplus donation within a food manufacturing industry [6]. A possibility to quantify some social aspects, which would facilitate the integration of these aspects into quantitative operational management research can improve the ability of food processing businesses in a corporate social responsibility area. Specifically, improvement of production planning processes and on-contract based donations of ready-made meals surpluses can contribute for reducing food waste and diminishing transactional cost in that context.

The growing trend in the use of food banks is linked to changes in welfare and the reduction of local government budgets, which provides evidence that the standard of living and the rate of use of food banks are interlinked [7, 8]. The traditional system of food banks in the United States faces a number of challenges as well, such as those related to the consumption of unhealthy industrial foods and the clients' long-term dependence on food bank services. Most food banks measure their efficiency by the quantity of food distributed, because the weight of distributed food is considered to be an objectively usable indicator. Food banks usually have no ambition to alleviate poverty itself. However, some food banks are looking for more proactive solutions to the needs of their community [9]. It can be seen many of the identified benefits of food banks in the UK in the context of the fact that these are standing outside official social security structures. This study therefore suggests that food banks should maintain their independence from the state. This independent position will allow to maintain the benefits of flexibility and informal relationships with their users. Authors also emphasize that food banks have in fact no ambition to replace statutory social benefits and social services [10]. 
A conducted survey among 96 food banks across 13 European countries in year 2014 provided descriptive statistical analysis of age, paid and voluntary work, volume of food distributed and the number of visiting people. The DEA-based analysis of the effectiveness of food banks was done to identify efficient and inefficient food banks, set benchmarks and potential improvements over relevant estimates. There have been identified significant inefficiencies in this sector. Some food banks, whose best practices should be researched and adapted by inefficient organizations, operate much more efficiently than the average. If all food banks achieve higher efficiency in the future, the amount of food distributed, resp. clients of these food banks can rise. Authors state that there is room for improvement in the work of food banks, which means that existing food banks can, with the help of cooperating organizations, make a greater contribution to the relevant interest groups [5].

Increasing efficiency specifically in keeping quality and reducing food waste within cold chain operations can be also mentioned in the aforementioned context. It is specifically discussed that the cooling chain for food donated to banks typically begins with the collection of goods from the donor. Refrigerated vehicles are used, which deliver the donated goods to the food bank's warehouse. Decisions on the storage of donated food (including chilled and other perishable one) due to their minimum acceptable level of quality and safety are typically made by volunteers with basic training on control procedures. Food that have not passed this type of inspection are subsequently composted or disposed. So, it is proposed for food bank to actively implement inventory management strategies supported by ICT facilities, involving other enhanced quality monitoring approaches, such as dynamic shelf-life prediction based one [11].

Interviews conducted within food bank network in the United States in 2015 that included 61 local agencies as a random sample of respondents identified a perception of its participants that related cost-savings help to operate participating single standing non-profit organizations in that network. Nevertheless, it still persisted the need for enhancing communication and consequent collaboration between networked entities [12]. Another identified survey in this area was conducted among independently operating food banks in England, i. e. apart from the largest food bank franchise Trusssell Trust. They surveyed a sample of 114 food bank, using interview. Main finding of that research is that operation of independent food banks is varying regarding to its nature of operating groups and way of their operating and that their operation is heavily depended on volunteer labour and public donations [13]. It can be also stressed the contribution of local food environments within food banking in the United Kingdom. Above all, it is pointed out at a need for rethinking of concepts within food banking operations in order to build a better evidence and information base for food and welfare systems [14]. Other exploration study on food bank practise was focused on experiences of asylum seekers in Australia with active using of foodbanks system to help with food insecurity. Authors of that study identified some cultural and religious constrains within provisions of food help to asylum seekers [15]. Operations research on food banks' activities is also a common area of interest. On of this type of studies identified respective proposals on inventory management and scarce resources distribution, using the case of the Greater Chicago Food Depository in the USA in order to stress the need for its equitable and effective service by sequential resource allocation approach. So, this fact steps behind the traditional problem concept of profit maximization decision making process by seeking a balance between the supply and demand sides within food banks' operations [16]. Contrarily, there exist discussions on food banking in Canada, the USA and the UK as a neoliberal kind of approach for involving corporate sector in solving two rather contradictory situations - surplus of food versus low wages and insecure employment. In addition, it is stressed also a problem area of addressing governments' responsibilities on wellbeing that is substituted by charity initiatives in this field of interest [17-19]. The case of Netherlands then points out at budget limitations and financing 
discontinuity from public administration that is negatively influencing investments of food banks into improvement of their services and quality within food help provision [20].

\section{Methods and Resources}

The review type article is based on a research of the current state of knowledge in the field of effective activity of food banks, which uses methods of analysis and synthesis of both foreign and domestic information sources. Partial outputs of the ongoing research of efficiency aspects of the activities of food banks in the Czech Republic were also used for the elaboration of this contribution. A descriptive financial analysis of 7 regional foodbanks active in the Czech Republic was conducted according to availability of publicly accessible financial data within the public register. Namely, there were employed the following financial analysis indicators:

Debt Ratio $=$ Total Debts $/$ Total Assets

Current Ratio $=$ Short Term Assets $/$ Short Term Liabilities

Quick Assets Ratio = (Short Term Assets - Inventories) $/$ Short Term Assets

Cash Position Ratio $=($ Short Term Financ. Assets + Cash $) /$ Short Term Liab.

Return on Assets $=($ Earnings Before Interest and Taxes $) /$ Total Assets

\section{Results and Discussion}

Food banks in their current form were set up in the Czech Republic after year 2014. A prevailing legal form of that social type of companies is a community interest company. Despite the fact that community interest companies are not intended to meet profitability goals of their stakeholders, this legal type of companies have to be managed similarly to business entities in the area of financial management issues. Fig. 1 provides an overview of selected financial indicators of active food banks in the Czech Republic, covering assets and liabilities side and also insight into the potential of shareholders' funds creation via the earnings before interest and taxes indicators (EBIT). It has to be added that indicator EBIT is covering also the operational subsidies to food banks from public budgets, i.e. that indicator can be considered as a proxy for their possible development by long term capital allocation.

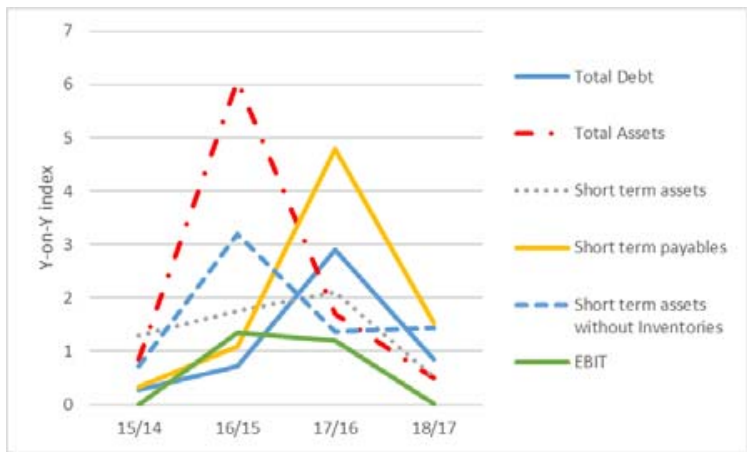

Fig. 1. Development of selected financial indicators' mean value measured by Year-on-Year index; Source: Own work using publicly accessible data via Ministry of Justice [21]

There is an obvious development of property structure of active foodbanks after year 2015, thanks to investment subsidies from public budgets. It was also introduced a new operational subsidies scheme for active food banks in Czech Republic in year 2016. Effects of this type of operational subsidies based on coverage of eligible operational expenditures can be identified in an increase of EBIT indicator after year 2015. Increase of operational 
cost in following years however influenced a decrease of operational profit. Further insight into financial position of food banks active in the Czech Republic is provided via selected indicators of financial structure, ability of payment and profitability. For an overview in time period of years $2013-2018$ see Fig. 2 .

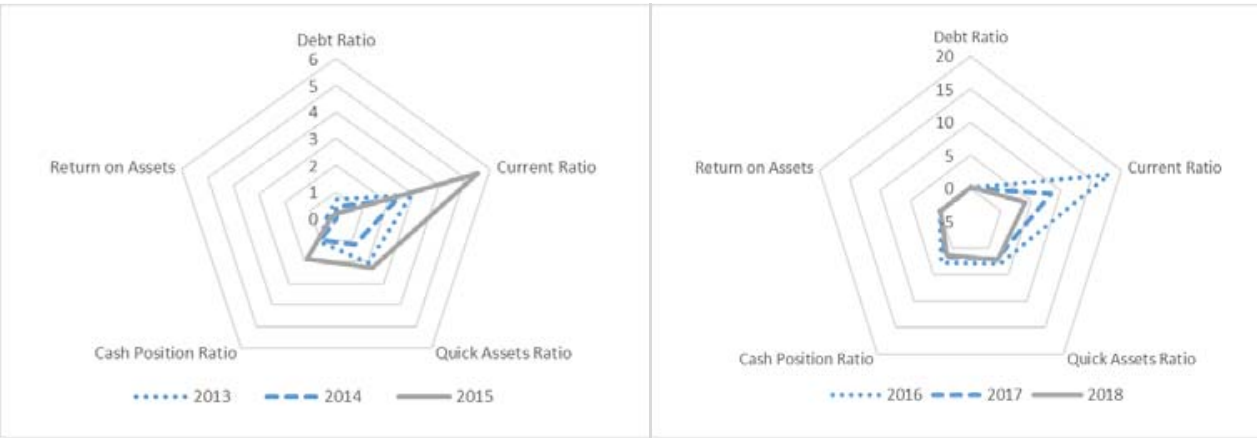

Fig. 2. Development of selected financial ratio indicators' mean values in respective years; Source: Own work using publicly accessible data via Ministry of Justice [21]

Development of food banks' payment ability via observation of the indicator Cash Position Ratio identifies their bettering off position, especially after year 2015. This fact is again interrelated with operational expenditures' subsidies and provides to food banks a stable position for recovering of short term payables. In a similar manner, it can be assessed a Quick Assets Ratio and Current Ratio development which enormously exceeds after the year 2015 their generally recommended values. Consequently, low levels of indebtness can be a recognisable effect of subsidies to foodbanks, specifically in spite of increase of long term assets for increasing food redistribution capacity of active foodbanks. Conversely, very low profitability levels of food banks measured by Return on Assets are observed also under financing scheme of operational subsidies. It can be argued on one hand that food banks service as community interest companies, which are not intended to meet profitability goals itself. On the other hand, the fact of low operational income does not allow creation of long term shareholder funds for their further development.

\section{Conclusion}

Service of food banks in the Czech Republic can currently be considered as regionally established, with their network currently consisting of 14 food banks at the regional level and a central food bank based in Prague, providing partial redistribution of donated food. Food banks provide assistance to people in material need through charitable and humanitarian organizations acting as cooperating organizations of the relevant regional food bank. The subsidy support by the government is currently indispensable for the activity of the mentioned food banks. These are not only subsidies for the operation of food banks, but also for investments related to the possibility of expanding their storage capacities. Although the current state of financial support for ensuring the activities of food banks by the government authorities can be assessed positively, the effort to change the scheme of financing food banks in the Czech Republic is intensifying. Results of conducted financial analysis also pointed out at the need to ensure future development for the activities of food banks by the shareholder funds. This article is a partial output of an 
ongoing research within project of specific research aimed at identifying current trends and best practices of sustainable operation of food banks in the Czech Republic.

This article was prepared as a partial output of project financed by Internal Grant Agency of FBE MENDELU in Brno, grant no. PEF_TP_2020003 "Aktuální trendy a nejlepší praxe pro zefektivňování činnosti potravinových bank v ČR".

\section{References}

1. Caraher, M., \& Furey, S. (2018). Growth of food banks in the UK (and Europe): Leftover food for leftover people. In The Economics of Emergency Food Aid Provision, 25-48.

2. Lipinski, B., Hanson, C., Lomax, J., Kitinoja, L., Waite, R., \& Searchinger, T. (2013). Reducing food loss and waste. World Resources Institute Working Paper, 1, 1-40.

3. Soon, J. M., Manning, L., Dani, S., Fassam, L., Jackson, E., \& Farag, K. (2016, July 13). Reduce surplus food: linking corporate donors and food banks. Retrieved from: https://pure.northampton.ac.uk/en/publications/reduce-surplus-food-linking-corporatedonors-and-food-banks.

4. Ministry of Agriculture of the Czech Republic. (2019, April 10). Ministerstvo zemédělství podporuje a i nadále bude podporovat potravinové banky. Ještě letos se bude snažit o navýšení finanční podpory. Retrieved from: http://eagri.cz/public/web/ mze/tiskovy-servis/tiskove-zpravy/x2019_ministerstvo-zemedelstvi-podporuje-a-i.html

5. Gonzalez-Torre, P., Lozano, S., \& Adenso-Diaz, B. (2017). Efficiency analysis of the European food banks: Some managerial results. VOLUNTAS: International Journal of Voluntary and Nonprofit Organizations, 28(2), 822-838.

6. Buisman M. E., Haijema R., Akkerman, R. \& Bloemhof J. M. (2019). Donation management for menu planning at soup kitchens. European Journal of Operational Research, 272(1), 324-338.

7. Loopstra, R., \& Lalor, D. (2017, June 30). Financial insecurity, food insecurity, and disability: The profile of people receiving emergency food assistance from The Trussell Trust Foodbank Network in Britain. Retrieved from: https://www.trusselltrust.org/wpcontent/uploads/sites/2/2017/06/OU_Report_final_01_08_online.pdf.

8. Bacon, Ch. M. \& Baker, G. A. (2017). The rise of food banks and the challenge of matching food assistance with potential need: towards a spatially specific, rapid assessment approach. Agriculture and Human Values, 34(4), 899-919.

9. Ballantyne, K., Baylor, R., Bowe, A., \& Stewart, J. (2015, April 30). Expanding Food Bank Impact: Healthy Food and Sustainable Farm Production. Retrieved from: https://sites.lsa.umich.edu/sustainablefoodsystems-2/wp-content/uploads/sites/546/201 6/05/FINAL-PAPER.pdf.

10. Wainwright, D., Buckingham, A., \& Wainwright, E. (2018). Why do people use food banks? A qualitative study of food bank users in an English city. Voluntary Sector Review, 9(3), 311-329.

11. Gharehyakheh, A., Krejci, C., Cantu, J., \& Rogers, J. (2020). A Multi-Objective Model for Sustainable Perishable Food Distribution Considering the Impact of Temperature on Vehicle Emissions nad Product Shelf Life. Sustainability, 12(16), 6668.

12. Parker, M. A., Mook, L., Kao, C. Y., \& Murdock, A. (2019). Accountability and Relationship-Definition Among Food Banks Partnerships. VOLUNTAS: International Journal of Voluntary and Nonprofit Organizations, 1-15. 
13. Loopstra, R., Goodwin, S., Goldberg, B., Lambie-Mumford, H., May, J., \& Williams, A. (2019). A survey of food banks operating independently of The Trussell Trust food bank network.

14. Thompson, C., Smith, D., \& Cummins, S. (2019). Food banking and emergency food aid: expanding the definition of local food environments and systems. International Journal of Behavioral Nutrition and Physical Activity, 16(1), 1-3.

15. McKay, F. H., Bugden, M., Dunn, M. \& Bazerghi, Ch.(2018). Experiences of food access for asylum seekers who have ceased using a food bank in Melbourne, Australia. British Food Journal. 120(8), 1708-1721.

16. Lien, R. W., Iravani, S. M., \& Smilowitz, K. R. (2014). Sequential resource allocation for nonprofit operations. Operations Research, 62(2), 301-317.

17. Lightman, E. S., Mitchell, A., \& Herd, D. (2008). Globalization, precarious work, and the food bank. J. Soc. \& Soc. Welfare, 35(2), 9-28.

18. Loopstra, R., Reeves, A., Taylor-Robinson, D., Barr, B., McKee, M., \& Stuckler, D. (2015). Austerity, sanctions, and the rise of food banks in the UK. Bmj, 350, h1775..

19. Riches, G. (2018). Food bank nations: Poverty, corporate charity and the right to food. Routledge.

20. Van der Horst, H., Pascucci, S. \& Bol, W. (2014). The "dark side" of food banks? Exploring emotional responses of food bank receivers in the Netherlands. British Food Journal, 116(9), 1506-1520.

21. Ministry of Justice of the Czech Republic. (2020, September 8). Public register. Retrieved from: http://www.justice.cz. 